\title{
Linking Natural Resource Management to Tourist Satisfaction: a study of Australia's Great Barrier Reef
}

\author{
Alexandra Coghlan \\ International Centre for Ecotourism Research \\ Griffith University \\ Gold Coast, Australia \\ a.coghlan@griffith.edu.au
}

To cite this article: Alexandra Coghlan (2011): Linking natural resource management to tourist satisfaction: a study of Australia's Great Barrier Reef, Journal of Sustainable Tourism, DOI:10.1080/09669582.2011.614351

This paper challenges the accepted tenet that conservation creates attractive tourist experiences and high satisfaction rates, and explores the nature and value of partnerships between protected area managers and tourism operators. It develops a model to examine the linkages between natural resource management and naturebased tourism industry performance. The model uses input measures, (such as the expertise and financial resources put into maintaining a healthy ecosystem), output measures, (visitor perceptions of the environment and their experience of it), and outcome measures (satisfaction scores), to examine these linkages. Whilst the links between input, outputs and outcomes appear relatively weak, results suggest that operators can strengthen those links through high service quality, effective interpretation, in order to produce higher visitor satisfaction. The relationship between the natural environment itself and satisfaction was less clear, perhaps symptomatic of the "messiness" of protected area tourism systems where cause and effects are not always clear. The study suggests that perceptions of the natural environment and the nature-based tourist experience are best mediated through the tour operators' input into creating and maintaining quality staff, to complement and demonstrate inputs by protected area managers, within the context of long-term partnerships between natural resource management and nature-based tourism.

Keywords: protected area, visitor experience, partnerships, sustainable tourism. 
Introduction

Nature-based tourism, particularly in protected areas, can create uneasy interfaces between the business models of the tourism industry and the "business models" of natural resource managers (Fennel \& Smale, 1992; Shultis \& Way, 2006). As a direct result of these interfaces, formal and informal relationships are created between tourists, tour operators and natural resource managers. These relationships, sometimes described in the literature as public-private partnerships, form frameworks around which tourism is often organised, again formally and informally, in protected areas (Buckley, 2002).

The research detailed here was designed to explore those interfaces and test some of the assumptions commonly associated with them. For instance, how true is it that tourism businesses working in natural protected areas benefit from investment, usually by the public sector, in conservation measures? It has also been a contested tenet of sustainable tourism for many years that a well conserved and managed natural resource, used by responsible tour operators, will create experiences that are attractive to tourists, and which in turn will produce outcomes that can be measured through high visitor satisfaction and referral rates (see Krippendorf, 1982; Lane, 1994). This research tests that belief, and challenges the strength of the links between conservation investment, quality of the natural environment and visitor satisfaction in protected area tourism.

The approach adopted in this study recognises that shifts have occurred within the previously established linear, reductionist paradigm in both social and natural sciences, yet suggests that there is evidence that it has not totally been forsaken when dealing with questions such as the one posed here. Thus, the argument that improved natural environments leads to better tourism experiences is commonly heard at 
informal partnerships meetings, as well as in public policy discourse. Indeed the argument may often take a central role in the conservation of natural areas. However, it may be that the tight coupling of conservation and tourism benefits is slowing the move towards truly sustainable tourism that both protects the environment and considers visitor experience within protected areas (c.f. Hall, 2010). The aim of this paper is, therefore, to devise and test a simple model to depict the flow-on effects of inputs that create the links between nature-based tourism partners, and which are designed to achieve the shared goals of visitor satisfaction, positive word of mouth and thus, indirectly, support for the protected area (McCool, 2006).

\section{Tourism and protected area management partnerships:}

A number of researchers have examined the interactions that have developed between diverse stakeholders groups, such as protected area managers and businesses, as they willingly (or occasionally unwillingly), interact to maximise the benefits each group hopes to derive from partnerships for conservation. Some authors (Buckley \& Sommer, 2001; Dixon et al., 1993; Figgis, 1993; Griffin \& Vacaflores, 2004; Laing et al., 2008; Wood, 1991) have provided detailed overviews of the types of publicprivate partnerships. For example, Laing et al. (2008) noted that one of the benefits of public-private relationships has been the maximization of carrying capacity, profits and visitor satisfaction. In a special issue of the Journal of Sustainable Tourism devoted to tourism and national park partnerships, Moore and Weiler (2009) also suggest that such partnerships lead to improved or sustained environmental quality, public support for conservation goals and an increase in revenue from user fees and donations. 
Many of the arguments for conservation of natural areas centre on their economic value to the local region through tourism revenue, and shared conservation goals between private industry and natural area management (Buckley, 2002). Steffen (2004, p.55) for instance, illustrates the tight coupling of nature-based tourism's economic value and nature conservation efforts by opening her article on parks and tourism partnerships with the sentence "much of Australia's $\$ 70$ billion p.a. tourism industry is based on the attractions of the country's natural environment". She goes on to say that links between conservation and tourism business can be created if opportunities can be identified. She focuses on the common needs between these partners as a basis for these links, including:

- Creating more areas that protect biodiversity and ecosystems

- Better customer service, including interpretation

- Conservation, visitor management and monitoring

- More tourism products that are ecologically, economically and socially sustainable.

- Generating income for the surrounding community (p.67).

Some authors, however, have identified both a marketing-planning gap and a use-conservation gap that can arise between managers, marketers and resource users (Jamal \& Stronza, 2009). This gap occurs as destination marketing organisations focus on marketing and promotion and are not closely involved in conservation and planning for sustainable use (p.171). In addition, management for sustainable use may also be separated from management for conservation, resulting in a use-conservationgap. The existence of such a gap may complicate the effectiveness of partnerships as they relate to the common goals outlined above. Steffen (2004) also draws attention to operators' lack of control over the image promoted, and because they have no property rights over the protected area, their product quality and reliability is to some extent shaped by park agency decisions. For example, in accordance with their 
conservation mandate, park managers must make decisions about animal populations (e.g. culls, pest/invasive species removal, translocations), application of fire regimes, vegetation removal, road/path access or closures, crowding, and so forth, all of which will affect the nature and quality of the visitor experience provided by commercial tour operators.

Despite the partnerships rhetoric, there are clearly areas of potential conflict between the goals of conservation and the provision of visitor experiences. Indeed, often issues arise based on misunderstandings between park managers and tourism operators, who often "talk at cross-purposes, sometimes using the same language but with different meanings" (Steffen, 2004, p.63). More recently, academics have highlighted the "messy" or "wicked" nature of protected area tourism planning (McCool, 2009; Rittel \& Webber, 1973). Messiness is considered to be an environment characterised by change, complexity and uncertainty, where the traditional cause and effect relationships may be more difficult to identify (McCool, 2009), whilst "wicked" problems are characterised by the absence of an absolute truth, subjectivity in the definition of public good, and the absence of definite answers and optimal solutions (Farsari et al., 2010; Rittel \& Webber, 1973). This in turn adds to complications listed above when bringing together different nature-based tourism stakeholders to work on common goals or outcomes.

Brechin et al. (2002) discuss conservation partnerships in a broader sustainable development context. They highlight the need to understand issues in participation, including who participates, what are their demands and expectations, in what capacity do individuals and groups participate and how do they benefit from participation (p.47). They also question how effectively participants pursue their goals and the effectiveness of outcomes associated with action. It may be argued that these 
questions have not been subject to a detailed examination in most tourism and protected area partnerships. Thus, periodic reviews of the nature of the relationships between conservation and tourism experiences can be a useful exercise. Indeed, Hall (2010) argues for a new understanding of the links between natural capital and tourism, that challenges existing paradigms operating within the sustainable tourism discourse.

This paper examines one aspect of the links between natural resource managers and commercial tourism operators, and tests the popular assertion that common goals do exist in the form of a well-managed natural environment's contribution to visitor satisfaction in nature-based tourism. It recognises the tightly coupled rhetoric around tourism's economic contribution to protected areas and the need for high quality natural environments. In doing so it questions the continuing dominant paradigm based on neoliberal approaches to sustainable tourism, and economic justifications for the protection of the natural environment (c.f. Hall, 2010), that perhaps underlie the drive towards a partnerships approach to tourism in protected areas.

\section{Visitor satisfaction as a measure of success for tourism in protected areas:}

Visitor satisfaction is a particularly important consideration in protected area tourism as satisfaction scores are used as a measure of success, or failure, of a protected area to deliver a high quality visitor experience. Examples where the discourse of valuing protected areas for their economic benefits via tourism (and thus the importance of satisfactory visitor experiences) are frequently noted in public policy statements. For instance, in a speech to the Tourism and Transport Leaders Summit in 2009, a spokesperson for Australia's Federal Government's Department of Environment, Water, Heritage and the Arts (DEWHA) stated that "there are obvious 
benefits in working together to meet our common goals to ensure the long-term sustainability of the tourism market for our assets". She elaborated by pointing out DEWHA's and the tourism industry's "shared goals of protecting, showcasing and capitalising on our natural and cultural assets" (Kruck, 2009) (author's italics).

Emphasising tourism satisfaction as joint goal of tourism/protected area partnerships is deemed appropriate as a number of parks adopted a service-quality goal-oriented to visitor satisfaction (Jamal \& Stronza, 2009), and the profitability of nature-based tourism operators also relies on being able to give customers a consistently high quality experience (McKercher \& Robbins, 1998). Satisfaction is therefore commonly seen as a joint goal which brings together the other goals of sustainable businesses, increased support for conservation, revenue from visitor fees and so forth. In addition, satisfaction might also be understood as a pre-requisite for the deepest level of the recreation demand hierarchy put forward by Driver and Brown (1978). At this level, benefits are experienced as a result of satisfactory recreational experiences. McCool (2006) suggests that benefits from a high quality experience may result in additional support for a protected area, and accelerating interest in conservation. Eagles (2002a) put the link more directly: "nature-based tourism...is heavily dependent upon two fundamental components: (1) appropriate levels of environment quality, and (2) suitable levels of consumer service." (p.132). Understanding satisfaction in protected areas may be a challenging exercise, in part because nature cannot be controlled in the same way as many other attractions, and therefore traditional, attribute-based approaches and expectation-performance gap measures may be less useful where services are only one element of the opportunities and experiences provided (Tonge \& Moore, 2007). There has, therefore, been an increasing trend in satisfaction studies to recognise the holistic nature of satisfaction 
that considers the provider's service quality, affective and cognitive components of the broader experience, the role of the tourist him/herself in shaping his or her satisfaction, whilst also providing useful managerial information to protected area managers (Baker \& Crompton, 2000; Bigne et al, 2005; Fletcher \& Fletcher, 2003; Otto \& Ritchie, 1996; Ryan \& Cessford, 2003).

In this research, a case study approach is adopted to understand the links between protected area / tourism partners in one of Australia most iconic tourist attractions, the Great Barrier Reef (GBR). In the following sections, the test case for this study, the Great Barrier Reef Marine Park (GBRMP), is described, followed by a proposed model to test the links between natural resource managers and commercial tour operators. The characteristics of the test case that are of interest to this study are highlighted to show points where protected area goals and tourism goals overlap, either intuitively or through evidence from prior studies (e.g. Harriot, 2002; Williams \& Polumin, 2000; Uyarra et al., 2005; Rudd, 2001), as they are believed to affect visitor satisfaction.

\section{The Great Barrier Reef as a test case, and a model for partnership outcomes}

In this study, it is demonstrated how this model operates in a protected area using Australia's Great Barrier Reef Marine Park as a case study. The reef system stretches along the north east coastline for 2000 kilometres creating an inner reef lagoon and a reef structure that supports about $40 \%$ of the world's coral (Kenchington \& Day, 2011). In the last three decades the reef has become one of the key attractions for Queensland's fast growing tourism industry supporting the economies of major entry points at Cairns and the Whitsunday Islands (Moscardo et al., 2004). In 1981 the reef was listed as a World Heritage Area. It is managed by the Great Barrier Reef 
Marine Park Authority (GBRMPA) with funding provided by the Australian Federal government, whilst day to day management is undertaken by the Queensland Department of Environment and Resource Management (Kenchington \& Day, 2011).

The case study selected for this study offers a number of advantages. Under its World Heritage status, there is an obligation to present its heritage values to the wider community, and as pointed out by Chadwick (2004), the off-shore location of the Reef and associated access issues, means that most visitors would experience the reef with commercial tour operators. Moreover, the significance of the GBR to the region is well documented; it is estimated to contribute AU\$6 billion to the local economy and to employ 55,000 people (GBRMPA, 2007). The area has also been the subject of an extensive study by Huybers and Bennett (2002) on environmental management and the competitiveness of nature-based tourism destinations, describing the role that environmental management plays in the strategic marketing of a nature-based tourism destination. They provide evidence that environmental protection agencies can assist in enhancing the image and developing the reputation of the protected area in a manner that benefits the local tourism industry.

For some years now, the GBRMPA has endeavoured to establish strong links with the tourism industry, as well as undertake their strategic visions of ensuring "a healthy reef for the future". Their initial focus was to explore how to develop "a real partnership to manage the Reef by harnessing the entrepreneurial drive of the private sector to ensure environmentally compatible development" (Chadwick, 2004, p.95). According to Schluter et al. (2007), and other representatives of institutions with a mandate to protect the reef (e.g. the quotation from DEWHA provided above, and the extract from the Sydney Morning Herald provided below), the GBRMPA and the tourism industry share a strong set of common goals that recognize that a healthy reef 
leads to a healthy tourism industry. For individual tour operators, engaging in a partnership with natural resource managers provides tangible benefits (longer permits, marketing opportunities) as well as broader benefits as the reef is protected from other, perhaps less sympathetic practices (GBRMPA, 2009a).

On a practical level, the links between the Authority and the private sector are maintained through regulation, supply of services and consultation (Chadwick, 2004). Regulation includes collection of user fees, issuing of permits, eco-accreditation and zoning. Services supplied include biodiversity monitoring programs and interpretation packages for delivery by reef tour operators. Consultation occurs through formal consultative mechanisms and, on a more informal level, between GBRMPA staff and operators (Kenchington \& Day, 2011). Furthermore, growing concern over the water quality of the GBR and its impact on biodiversity conservation has led to an extensive partnership between the Australian Government and the Queensland State government to improve water quality. Water quality issues include nutrient and suspended sediment concentrations, as well as toxicants including pesticides, all of which affect the growth and health of corals and more generally the Reef's ecosystem balance (Fabricius et al., 2005). Two major management projects have been funded by the Federal Government to improve water quality and develop management responses to climate change and fisheries-related pressures.

Using the partnerships links that exist between the GBRMPA and the tourism industry, a simple model (described below) can be used to illustrate how natural resource managers' tourism-related inputs create a visitor experience (a partnership output), whose quality can be measured using visitor satisfaction (i.e. the partnership outcome). If this input, output and outcome link is strong, a feedback loop is created which cycles back to the input stage, encouraging continued investment in inputs. 
Where the links are weak, it may be that either the level of inputs needs adjustment, that the partnership needs fine-tuning to take into account the responses at the outcome level, or that considerations beyond conservation and quality tourism experience outcomes are driving the partnership.

The type of model which uses input, output and outcome measures originated in accounting disciplines and is commonly used in management and organisations, particularly by not-for-profit organisations, for planning and change analysis. They allow relationships between efficiency (the input/output ratios) and effectiveness (output/outcome ratios) to be described and measured (Hendersen et al., 2002). For the purposes of this study, inputs are defined as the resources put into a project to deliver its outputs and may include management strategies and investment by the public and private sectors (Plummer \& Fennel, 2009), outputs are defined as the services and activities that are delivered as part of the project, in this case they are defined by the environmental quality of the protected area and the visitor experience, while outcomes are the changes and effects that happen as a result of the project, e.g. in a tourism/protected area partnership these can be the satisfaction assessments of the outputs by visitors to the protected areas. Closing the loop shown in Figure 1 occurs when positive outcomes measured as higher visitor satisfaction, are used to justify new inputs to continue the process of protection and where necessary remediation of the natural area involved. 


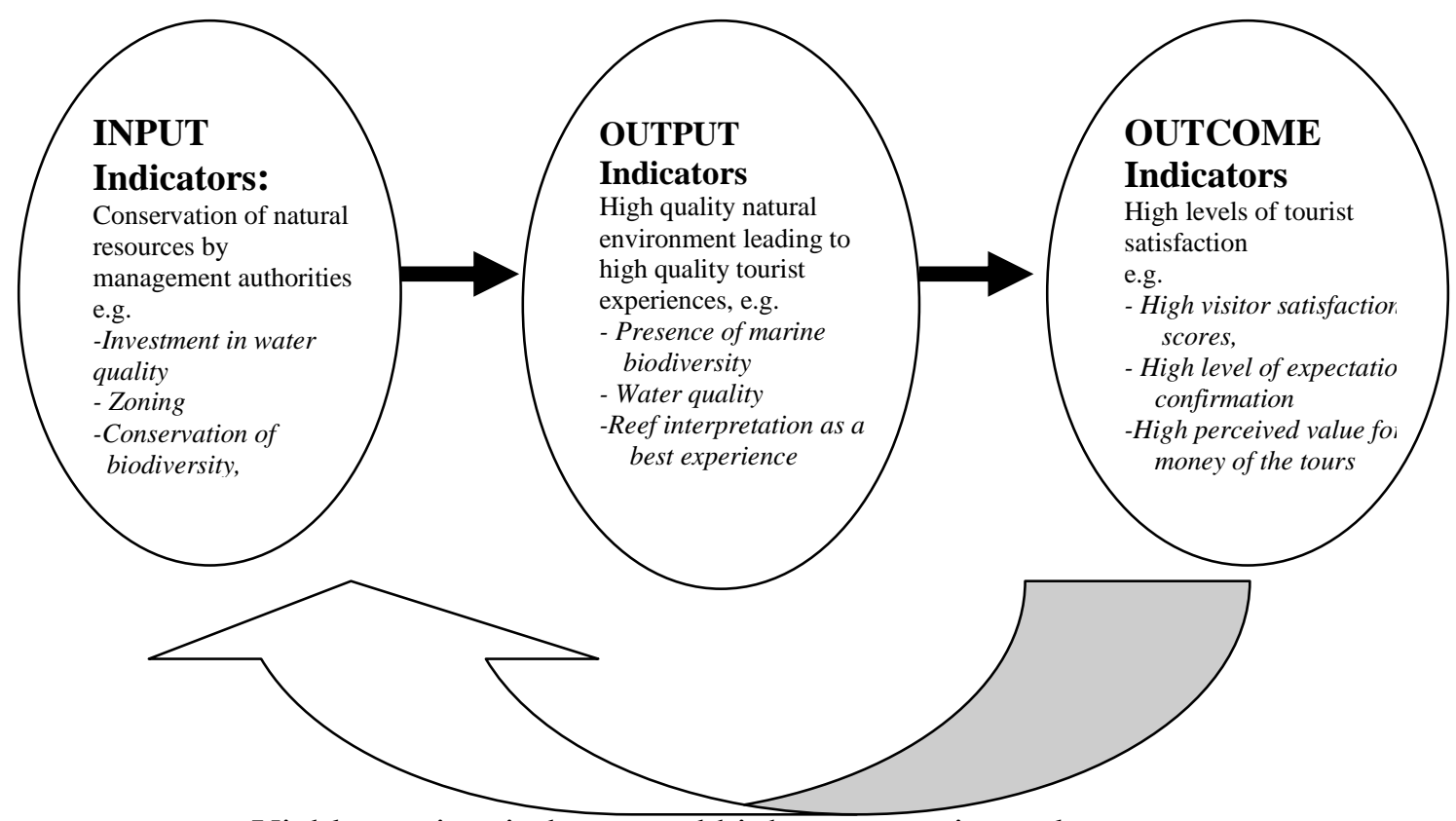

Viable tourism industry and high conservation value

Figure 1: Links between natural resource management and tourism operators (Source: Adapted from Herriman 2008).

\section{Research Aims}

Based on the ideas presented in Figure 1, this paper examines the relationships between natural resource management and marine tour operators' inputs and outputs measured by visitor satisfaction and recommendation levels. The aim is to test the strength of the links between the input stage of natural resource management and the outcomes stage using visitor satisfaction as indicators of success. The links tested are:

(1) managerial input into environmental interpretation, water quality, ecosystem health and biodiversity

(2) tourism output as measured by the importance of water quality, biodiversity and environmental interpretation in the experience, and

(3) tourist outcomes as measured by satisfaction.

In this way, we might start to examine one aspect of public-private partnership success in protected area tourism, specifically, changes to visitor satisfaction through investments in conservation measures. It must be noted that other forms of success 
also emerge from partnerships, particularly social learning, trust, communication and so forth, that are not tested in this study, as well as other more subtle exchanges between partners (c.f. Ecotourism Australia, 2002; Department of Environment and Heritage, 2004). Conversely other impacts of nature-based tourism on conservation are also not examined. The results must therefore be considered within the broader context of partnerships literature, and nature-based tourism/tourism and conservation literature.

\section{Research Methods}

The study is primarily based on quantitative and secondary data collection methods. Data on inputs were collected from a variety of secondary sources including natural resource management websites, information sheets, other published materials and primary sources based on informal discussions with GBRMPA staff and marine tour operators. Data on outcomes were collected through surveys of reef visitors. The visitor surveys form part of a larger project that examined aspects of the sustainable use of marine resources in the GBRMP ${ }^{\mathrm{i}}$.

The visitor surveys were distributed with the assistance of ten reef tour boat operators. These operators were chosen with the assistance of the Association for Marine Park Tourism Operators (AMPTO), the regional industry body that represents reef tour operators, to encompass the diversity of tours and activities available on the Reef. The participating operators therefore reflect a range of pontoon-based operators, small day trip operators, sailing boats, live-aboard dive boats, and resort islands. Crew from these marine tourism operators distributed and collected the surveys at four locations across the GBR (Far North Queensland, Townsville, the Whitsundays, and the Capricorn Coast). The surveys were given to participating operators in the first 
week of each month and they are asked to distribute them, along with a "thank you" postcard, to a maximum of 50 Reef visitors for the largest operators. At least one member of the crew of these operators was trained in survey distribution, and the author was present on the first day of data collection to assist with any survey distribution issues as they arose.

Crews on the boats were asked to randomise the distribution process by seeking out tourists at every third table, for instance, and thus respondent recruitment fell somewhere between a convenience and random sampling strategy. Monthly returns averaged 195 completed surveys. Information collected in the surveys included socio-demographic characteristics of reef visitors through close-ended questions, where respondents were asked to select their age group, gender and occupation; their travel patterns using close-ended questions, where respondents were asked to select their travel party membership, length of stay, accommodation, transport to the region; motivations based on five point Likert-scale questions, where respondents were asked to rate a number of motivations for their importance in choosing to visit the region; activities using close-ended questions, where respondents were asked to select all the activities they had undertaken at the reef; previous reef tourism experience through a mix of close-ended and open-ended questions, where respondents were asked if they had previously visited the GBR and other reefs and; overall satisfaction based on a Likert-scale question, where respondents were asked to rate their overall satisfaction with their reef trip on a scale of $1-10$, as well as measures of expectations (Likert-scale questions, where respondents were asked whether the tour/reef met their expectations from "greatly" to "not at all", best and worst experiences (open-ended questions), recommendations to others using close- 
ended questions, where respondents were asked to select from "yes", "no", "not sure", and finally, value for money (close-ended questions) (c.f. Coghlan \& Prideaux, 2009).

A total of 4800 surveys were collected between November 2006 and

December 2008. Table 1 provides a description of the main respondent

characteristics; they can be described as predominantly young and educated,

travelling with friends or their partner, and first time visitors to the region and to the

Reef.

Table 1 Summary socio-demographic and travel characteristics of GBR visitor survey $(\mathrm{N}=4800)$

\begin{tabular}{|l|l|}
\hline $\begin{array}{l}\text { Characteristics } \\
\text { Tested }\end{array}$ & Results \\
\hline $\begin{array}{l}\text { Socio- } \\
\text { demographics }\end{array}$ & 35\% Australian, 25\% students, 23\% professionals, 45\% 20-29 years old. \\
\hline $\begin{array}{l}\text { Travel } \\
\text { behaviour }\end{array}$ & $\begin{array}{l}28 \% \text { travelling with friends, 27.5\% travelling with their partner, 75\% first } \\
\text { time visitors to the region, 36\% staying in backpacker hostels for 2-5 } \\
\text { days, 57\% flew to the region, seeing the GBR, snorkelling and enjoy the } \\
\text { climate were the top travel motivations, 41\% used WOM and 34\% used } \\
\text { guidebooks for travel information }\end{array}$ \\
\hline $\begin{array}{l}\text { Reef trip } \\
\text { experience }\end{array}$ & $\begin{array}{l}\text { 69\% were first time GBR visitors, 36\% chose the trip based on agents' } \\
\text { recommendation, 41\% planned to dive, 45\% had visited other reefs, 75\% } \\
\text { went snorkelling, 53\% swam, 43.5\% went diving, and 13.5\% undertook } \\
\text { nowater-based activities. }\end{array}$ \\
\hline Satisfaction & $\begin{array}{l}\text { Mean satisfaction score was 8.49/10, 79\% perceived that they had } \\
\text { received value for money, 55\% said the reef greatly met their } \\
\text { expectations, and 61\% said the trip greatly met their expectations. }\end{array}$ \\
\hline
\end{tabular}

A content analysis of open-ended survey questions allowed themes that are important to the visitor experience to be identified and reported as output indicators. Visitor responses were also used to measure the perceived quality of the resource. Thus comments on water quality, biodiversity, the condition of the coral and the quality of interpretation become important indicators of the tourism-related effects of natural resource management inputs. Satisfaction, expectation (dis)confirmation, and perceived value for money are considered as outcome indicators because they are able to measure the quality of the experience. The data were analysed using SPSS16.00. 
To look for relationships between the variables chi-squared tests (Pearson's correlation) were used, and where nominal and interval data (satisfaction scores on a 10 point Likert-scale) were compared, Eta tests were used.

\section{Research Limitations:}

Several limitations should be noted in this research. First, the input indicators are mainly limited to the information that is publically accessible through natural resource management agencies, e.g. workshop materials, websites and publications. Further, the visitor survey methodology was dependent on the collaboration of operator crews. This approach may have led to some bias in the data collected as crew may have been more likely to approach guests in the vessels' salon, or English speaking visitors and so forth.

It must also be noted that this relatively simple approach was designed as a first step towards addressing the links between public/private partners as they move towards their common goals of high quality visitor experiences and high environmental quality. It considers only one aspect of the complex socio-ecological systems that form the links between nature-based tourism and conservation, and through its relative simplicity, attempts to speak equally to natural and social scientists with an interest in this area.

\section{Input Indicators}

The first step in the model was to identify inputs into the model. Inputs provided by the natural resource managers include water quality improvement programs, reef zoning schemes, the number of tour operators and commercial fishing licences 
allowed in the protected area, research, control of Crown of Thorns star fish and interpretive training (Chadwick, 2004).

\section{Water Quality}

Water quality is a key issue in the maintenance of the health of the GBR (Brodie et al., 2008) as well as a key factor in the level of enjoyment experiences by visitors as sediment loads, nutrient levels, and toxins affect visibility in the water and the health of the coral. The following excerpt from the Sydney Morning Herald online on highlights the sentiments regarding the importance of water quality to reef health and the industries that are dependent on it (and incidentally highlights the discursive coupling of tourism's economic value and conservation measures).

\footnotetext{
If we are to give our iconic reef the best chance of withstanding climate change, we must ensure its water quality is as clean as possible," Mr Heath [WWF reef spokesman] said. "It is astounding what we are allowing to happen to the reef."

Premier Anna Bligh last year flagged farming regulation and penalties after years of voluntary efforts to help save the reef had not worked. The announcement was unpopular with farmers but Ms Bligh said the reef would die if nothing was done. (...)

It's estimated the reef injects $\$ 6$ billion into the tourism economy each year and provides about 65,000 jobs.
}

(Reef water pollution: WWF, 2009)

Recent research has indicated that the water quality of the inner reef lagoon (the area between the coastline and the inner reef) has continued to decline in recent years as a result of agricultural run-off and increasing urbanisation (Brodie et al., 2008). In the Cairns section of the GBR for example there has been a $27 \%$ increase in nitrogen loads with a corresponding increase in phosphorus concentrations (GBRMPA, date unknown a). As a result, a total AU\$200 million was committed over a period of five years under a new water quality improvement program, Reef Rescue Plan (GBRMPA, date unknown a). The size of the investment reflects the 
high level of concern that exists over the need to protect the GBR through improving water quality.

\section{Biodiversity conservation}

The second input that enhances the reef environment is the conservation of biodiversity. Programs focus on climate change, conservation of protected species and management of fisheries. Climate change is becoming an increasingly important issue because of its deleterious effects on the health of coral communities and shellfish through increased water temperature and acidification (Hoegh-Guldberg, 2008). GBRMPA's climate change response programme includes a Coral Bleaching Response Plan which has been developed to monitor and assess the severity and extent of coral bleaching on the Great Barrier Reef each summer. The data generated through this programme assist on-going improvement of the systems developed to monitoring and predict weather conditions (GBRMPA, date unknown b).

The conservation plans for protected species include plans for some species of shells (including helmet shells, triton shells and tridacnid clams), some fish species (including seahorses, pipefish, sea dragons, potato cod, Queensland grouper, barramundi cod, Maori wrasse and all groupers (Epinephelus) over $100 \mathrm{~cm}$ in size, some species of shark (including whale sharks, grey nurse sharks and great white sharks) and other marine animals including freshwater sawfish, sea snakes, crocodiles, marine turtles, birds, seals, whales and dolphins, and dugongs (GBRMPA, date unknown c). Fisheries management is based on the marine park representative area zoning plans. The current zoning plan introduced in 2004 was designed to provide high levels of protection to key reef regions as well as allow access for tourism and commercial and recreational fishing (Kenchington \& Day, 2011). 


\section{Environmental Interpretation:}

As part of its partnerships with industry and under its World Heritage Status obligations, the GBRMPA has identified environmental interpretation as another area of investment (Chadwick, 2004), and interpretation is therefore considered an input in the context of this study. One of the main strategies in this area was the establishment of the Reef $H Q$, a large coral reef aquarium located next the Authority's head office in Townsville. It hosts approximately 100,000 visitors each year allowing them "to get up close and personal with the reef, while staying dry" (GBRMPA, 2009b).

For the two million tourists who visit the marine park itself, most commonly from the tourist towns of Cairns (approximately 400km to the north of Townsville) or Airlie Beach (approximately $350 \mathrm{~km}$ to the south of Townsville), the GBRMPA has developed responsible reef practices centred on education and interpretation for guides and operators (GBRMPA, date unknown d). This information is often available on-board, collated into a folder accessible to staff, and interpretation is often implemented by a marine biologist who may give a 10-15 minute presentation on the vessel as it makes its way out to the reef, guide snorkelling tours (sometimes as additional tours sold to the visitor), and who is generally on hand to answer questions in transit to and from the reef. Alternatively, vessels may use interpretive videos on the way to the reef, and may or may not include a marine biologist in their crew.

\section{Output indicators}

The next stage in the model is to trace the investment in conservation inputs to the tourism outputs indicated in the visitor experience. Outputs were measured as the presence or absence of features related to the input indicators mentioned above using results from the visitor survey. In this case study, the main output measures are related 
to water quality, and features concerning the health of the coral ecosystem and the quality of the interpretation provided during reef visits. In this study the importance of these features in the reef tourism experience were indicated by visitors' responses to the open-ended question "what factors influenced your satisfaction rating?".

Based on a content analysis of the responses, the natural environment (including marine biodiversity) was the second most frequently cited feature of their experience ( $24 \%$ of respondents, or $n=1152$ ) whilst interpretive activities were cited by $6.8 \%$ respondents $(n=288)$, and water quality was cited by $3.7 \%$ of respondents $(n=177)$. At a finer level of analysis, we note that 614 marine biodiversity-related comments were positive, as were the overwhelming majority of interpretation-related comments $(n=262)$. In the case of water quality, 42 of the comments were positive, another 48 felt that the water visibility and quality was poor, whilst the remaining 87 respondents who mentioned visibility did not specify whether it was good or bad. A few examples of both positive and negative comments regarding water quality, biodiversity and interpretation are provided below:

"I thought fish life would be more abundant. I thought I'd see sharks and turtles and manta rays".

"I enjoyed the informative and passionate way the staff and marine biologists are."

"I loved the variety of fish, saw sharks and turtles only disappointed with coral and water temperature".

On the other hand, the most frequently cited feature of the tour was the behaviour of the crew. The crew were cited by $49.2 \%$ of respondents $(n=2361)$ and of these comments, $79 \%$ (or $\mathrm{n}=1865$ ) of these comments were positive. Common descriptors of staff included "friendly", "funny", "caring", "reassuring", "professional", “courteous", "knowledgeable”, "helpful”, "passionate”, "attentive”, “encouraging”, “efficient". Only 19 respondents mentioned a negative experience with the staff, whilst the remaining 477 respondents were not specific regarding their perceptions of 
staff. Two other commonly cited features of the reef tours were the activities offered and the weather. Activities mentioned were diving, snorkelling, semi-submersible and/or glassbottom boat tours, helmet walks, helicopter tours, marine biology tours, fish feeding, swimming, and viewing the reef from underwater chambers. Over $23 \%$ of respondents $(\mathrm{n}=1104)$ mentioned their activities, including $550(49.8 \%)$ positive responses, and 98 (8.9\%) negative responses, often regarding cancelled tours and uncomfortable snorkelling conditions. Examples of comments regarding these three features (crew, activities and weather) are provided below.

"Crew were rude and abrupt".

"I was scared at first but felt safe with the people/crew to help if needed. Good safety practices".

Other categories of responses were also noted, albeit not as frequently as crew, the natural environment, reef activities and the weather. These included safety, food, the comfort and cleanliness of the boat, other passengers, the opportunity to share the experience with friends and relatives, the quality of the snorkelling equipment, the cost of the tour and the comfort and duration of the transit out to the reef.

The content analysis of tourists' responses about their reef experience indicates that some of the measures implemented by the GBRMPA as inputs do flow through to outputs. This was particularly true of marine biodiversity at the reef, and to a lesser extent, interpretation and water quality. The content analysis also pointed to additional experiential dimensions that relate to basic needs including safety, crew friendliness and the quality of food served on the tour boat. These outputs are more likely to arise from the inputs provided by marine tour operators. The following section identifies how these features come together in the outcome measures of visitor satisfaction, to further evaluate the direct impact on conservation measures on visitor satisfaction in tourism in protected areas. 


\section{Linking outcomes with inputs and outputs.}

Understanding how the features listed above are related to tourist satisfaction is a key feature of testing the links between inputs, outputs and outcomes in nature based tourism public-private partnerships. The outcomes that are used in this study focus on measures of satisfaction. In this case, three measures of satisfaction were available through the visitor survey; (i) a Likert-scale satisfaction score; (ii) a single-item expectation (dis)confirmation measures for both the trip to the reef and the reef itself; and (iii) perceived value for money. Figure 2 illustrates how these measures changed over the three years of data collection (2006-2008), with the mean monthly satisfaction scores recorded on the right hand scale (7.4-9.0) and the percentage of respondents who felt that reef and/or trip met their expectations and perceived value for money recorded on the left hand scale (0\%-100\% of respondents). Apparent correlations between the mean satisfaction score and the other variables were confirmed using an Eta test (Table 2). Eta is a measure of association that ranges from 0 to 1 , with 0 indicating no association and values close to 1 indicating a high degree of association. From the Eta results and for the purposes of this study, the Likert-scale satisfaction scores are used as a proxy measure for the three measures of satisfaction regarding the reef, trip expectation (dis)confirmation, and value for money. 


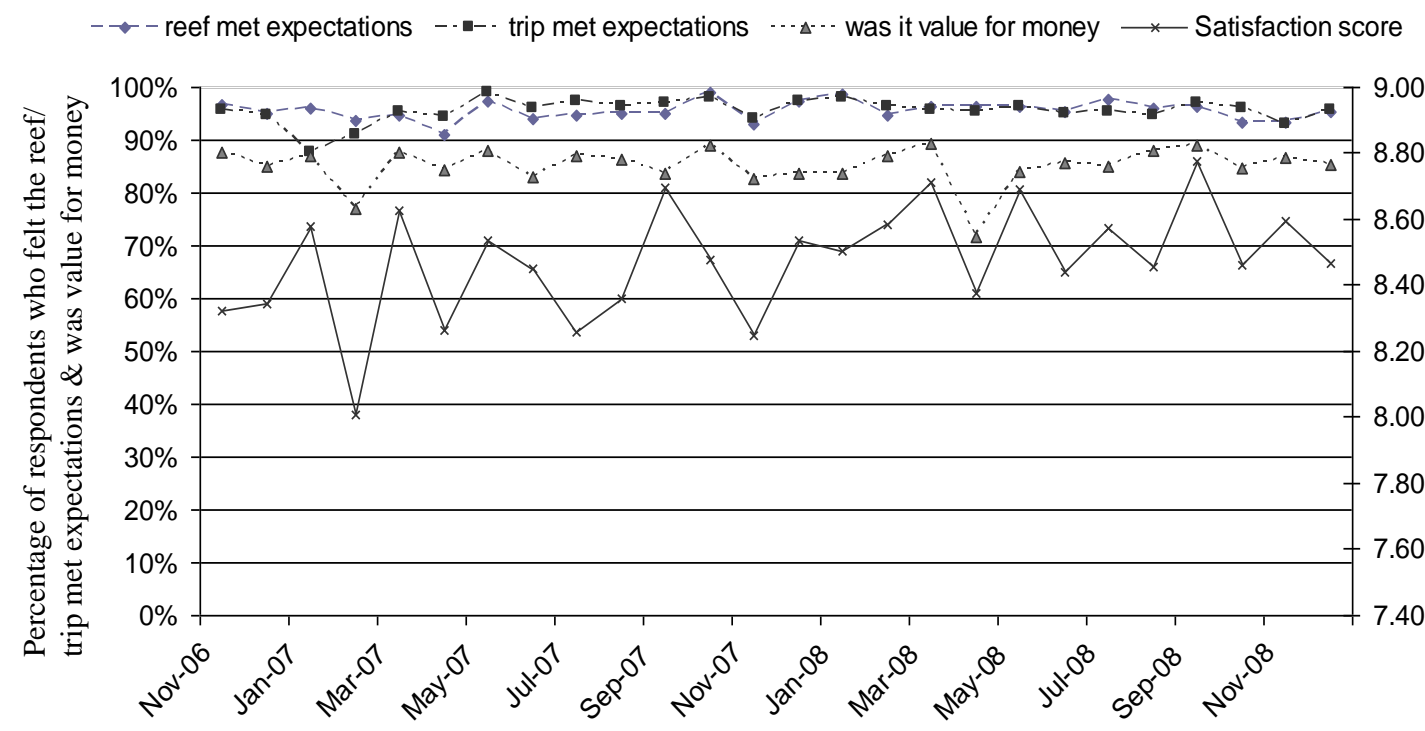

Figure 2. Changes in satisfaction measures for respondents between November 2006 to December 2008.

Table 2: Analysis of correlations between satisfaction measures.

\begin{tabular}{|l|l|l|l|}
\hline & $\begin{array}{l}\text { Reef } \\
\text { expectations }\end{array}$ & $\begin{array}{l}\text { Trip } \\
\text { Expectations }\end{array}$ & $\begin{array}{l}\text { Value for } \\
\text { money }\end{array}$ \\
\hline Satisfaction & 0.509 & 0.561 & 0.427 \\
\hline
\end{tabular}

Next, Table 3 compares the mean satisfaction scores between the six categories of trip features, taking into consideration both the positive and negative responses for each feature. The features are listed in descending order in Table 3 based on the mean satisfaction score associated with that feature. In addition, the mean satisfaction score's association with the variables were confirmed using an Eta test (Table 3).

Table 3: Respondents' satisfaction score in relation to the features that they felt influenced their satisfaction score. The three features of the model are highlighted in grey.

\begin{tabular}{lcccc}
\hline Feature & n & $\begin{array}{c}\text { Mean Satisfaction } \\
\text { score }\end{array}$ & $\begin{array}{c}\text { Standard } \\
\text { Deviation }\end{array}$ & $\begin{array}{c}\text { Eta test } \\
\text { value }\end{array}$ \\
\hline
\end{tabular}




\begin{tabular}{lcccc}
\hline Weather (positive) & 258 & 9.26 & 0.978 & 0.143 \\
Activities (positive) & 550 & 9.15 & 1.002 & 0.186 \\
Staff (positive) & 1564 & 9.09 & 1.013 & 0.338 \\
Interpretation (positive) & 255 & 9.06 & 0.943 & 0.105 \\
Marine Biodiversity/ & 533 & 8.98 & 1.079 & 0.135 \\
Health (positive) & 42 & 8.95 & 0.999 & 0.033 \\
Visibility (positive) & 252 & 7.14 & 1.523 & 0.262 \\
\hline Weather (negative) & 42 & 6.98 & 1.440 & 0.116 \\
Visibility (negative) & 98 & 6.98 & 1.514 & 0.178 \\
\hline Activities (negative) & 123 & 6.59 & 1.703 & 0.252 \\
Marine Biodiversity/ & 18 & 6.50 & 1.757 & 0.099 \\
Health (negative) & 19 & 6.26 & 1.661 & 0.114 \\
\hline Interpretation (negative) & Staff (negative) & & & \\
\hline
\end{tabular}

According to the results presented in Table 3, the mean satisfaction scores (outcome measures) associated with the three input measures are lower than the other three frequently cited features mentioned by respondents. This is reinforced by the results of the Eta test, which shows that the highest level of association was between satisfaction and positive interactions with staff. The next highest levels of association were between satisfaction and negative comments about weather, followed by negative comments about the marine life. The implications of this result are discussed in the following sections.

\section{Discussion}

The research presented in this paper aimed to link the inputs of natural resource managers to the outcomes of the protected area tourism sector as measured by tourist satisfaction through the intermediate output measures of tourist experiences. This type of approach to test the links between activities and behaviours of one party to the 
attitudes and behaviours of another related party is deemed appropriate when each party's successes becomes tightly coupled through public discourse, prevailing paradigms of adaptive co-management and shared governance, and include notions of joint, mutual goals. Thus the results are specific to protected area tourism within the context of public-private partnerships.

By examining the experiences of tourists over a 25-month period it was found that satisfaction measures appear to be poorly related to any one particular aspect of the tourist experience, as indicated by the results of the Eta analyses (Table 3). It is apparent that natural resource management agencies have correctly identified some of the major requirements for visitor satisfaction. Policies designed to enhance water quality are an essential input and appear to be the correct response from an ecosystem perspective as well as a visitor experience perspective. However, perhaps somewhat in contrast to public policy discourse, the investments in protected area tourismrelated issues have only a limited influence on visitor satisfaction.

As visitor satisfaction is one of the key outcomes for industry, and to some extent, the protected area managers, public-private partnerships may not be quite as clear-cut a relational practice as a superficial overview would appear to indicate. Instead tourism operators are expected (quite reasonably, given their access to a World Heritage Site) to have a minimal impact on the environment, whilst also providing most of the inputs into visitor satisfaction outcomes themselves. Marine tourism operators have certainly developed inputs that have resulted in highly favourable outcomes, and may in fact provide some of the most important ingredients to achieve common goals (c.f. Bushell \& Eagles, 2007). In the case presented here, it is noteworthy that boat crews have the greatest influence on satisfaction. The crew may in some cases modify perceptions of the natural environment, as indicated by this 
comment by a respondent: "although the clarity of the water was not what I expected Jason explained about the spawning which is incredible to witness". This last comment further illustrates the complexity of the relationship between input, output and outcome indicators, and supports Eagles et al.'s (2002b) conclusion that staff are "possibly the most important single factor in ensuring the successful management of tourism in protected areas" (p.145). Staff might therefore become a crucial input into public-private partnerships, requiring some effort to overcoming barriers to retaining quality staff (QTIC, 2008).

Interpretive activities, on the other hand, showed mixed results. They both contributed to satisfaction, whilst also being under-represented as key features within the satisfying or best experience aspects of the tour. Possible explanations for this trend might include the nature and scale of the attraction, tourists' limited prior knowledge, experience or understanding of the site, the manner in which interpretive activities are hampered by the attraction's physical context and conditions, and finally, the fact that understanding the site is only one of many tourist concerns (e.g. not drowning, using unfamiliar equipment, negotiating waves, currents, low visibility, overcoming fears of marine creatures and so forth) during the tour.

Emphasising industry's inputs into tourist satisfaction is very important within the partnerships model. For instance, Huybers and Bennett (2002) warn that superior environmental management ceases to contribute to competitiveness if the asset can be substituted or imitated (e.g. by a cheaper, more accessible competing destination). They suggest that in those cases "higher level resources such as reputation, customer loyalty and image become central to the region's competitiveness" (p.43). In cases where the tourism sector provides both financial support to the protected area, and may be considered one of the most significant rationales for conserving the natural 
area, there is a need to be absolutely clear what the inputs and outcomes are going to be in a partnership as well as establish follow up measures to see the inputs and outcomes are occurring.

In fact, the term "partnership" may actually be misleading as it may mask some of the different roles and responsibilities of "partners" as well as their type and amount of inputs and their desired outcomes. The findings presented here suggested that the relationship between output indicators and outcome indicators is complex and raise questions about what can in fact be said about shared, mutual goals, especially when stakes are high and the conservation and management of a precious ecosystem becomes tied to the subjective, socio-psychologically complex measure of tourism satisfaction.

Without a clarification of partners' contributions and a broader social political context for partnerships, the tight coupling of tourism and conservation (at least within public discourse) can lead to a very precarious position for one or the other. McCool's (2009) term "messy" becomes crucially important here as the weak links between inputs, outputs and outcomes suggests that effects (tourist satisfaction) are not tightly linked to causes (the state of the natural environment). In these cases "single-loop learning is not adequate" (McCool, 2009, p.141), and learning must not only focus on understanding cause and effect, but also the variables that govern the operation of the system.

This complex systems approach is largely the one adopted in natural sciences with the emergence of the adaptive co-management paradigm, as well as in tourism studies, with a number of scholars advocating the use of complexity theory to capture the non-linear, adaptive nature of tourism systems (c.f. Farrell \& Twinning-Ward, 2004, 2005; Farsari et al., 2010; Hall, 2010; McKercher, 1999). It is perhaps the case 
however, that both social scientists and natural scientists are still grappling to understand the complex, systems dynamics of tourism phenomena that occur at the boundaries of social and natural sciences, such as nature-based tourism in protected areas.

Finally, the question arises that should this coupling of tourism and conservation continue to be promoted through the partnership rhetoric, what might happen to conservation if the tourism system should alter or collapse, perhaps as a result of a tourism crisis (e.g. SARS, 9/11, GFC, etc)? In the current partnershipsbased approach to tourism in protected areas it could be argued that natural resource managers are capitalising on the connections between tourism income and the quality of the natural environment, to the extent that many conservation efforts would now appear to be dependent upon a healthy, profitable, and growing tourism industry. Sadly, this may leave conservation at risk from a fickle industry, where most components of the tourism system (tourism services such as transport to the region, accommodation, affordability, safety, alternative attractions and so forth) are beyond the sphere of influence of natural resource managers.

In summary, it is suggested that the model proposed here is a useful way of tracking the relationships between inputs, outputs and outcomes in protected area tourism as it relates back to effectiveness/efficiency analyses of change practices. The advantage of the model is that it may be adapted to a range of settings and used to identify disconnects between the inputs of firms and management agencies and the outcomes as perceived by visitors. It may be the case that neither tourism and conservation should become so tightly coupled that the success of one becomes dependent on the success of the other, arguably one unintended outcome of the current partnerships approach. Perhaps the term collaboration, which recognises areas 
of interdependence whilst allowing for areas of conflict, may be a more useful term than partnerships, which implies a certain level of co-dependence. Given the complexity of the two interacting systems (tourism and ecology) and the uncertainties that each faces, we do not really know what will happen to the tourist experience or the broader tourism industry in the case of a decline in coral health (output) or a decline in resources to manage the reef (input). All we can say for sure is that a diverse and beautiful ecosystem will be impoverished by diminishing conservation resources and lack of care for the reef and the world will lose one of its greatest natural wonders.

\section{Acknowledgements}

The author of this paper wishes to acknowledge the role of the Australian federal government's Marine and Tropical Science Research Facility in funding this research and Bernard Lane for his many helpful comments on the earlier drafts of this manuscript

\section{References}

Baker, D.A. \& Crompton, J.L. (2000). Quality, satisfaction and behavioural intentions. Annals of Tourism Research, 27(3), 785-804.

Bigne, J . E. , Andreu, L . \& Gnoth , J. (2005). The theme park experience: An analysis of pleasure arousal and satisfaction. Tourism Management, 26, 833 844.

Brechin, S., Wilshusen, P., Fortwangler, C. \& West, P. (2002). Beyond the Square Wheel: Toward a more comprehensive understanding of biodiversity conservation as a social and political process. Society and Natural Resources, $15,41-64$.

Brodie, J., Binney, J., Fabricius, K., Gordon, I., Hoegh-Guldberg, O., Hunter, H., O’Reagain, P., Pearson, P., Quirk, M., Thorburn, P., Waterhouse, J., Webster, I. \& Wilkinson, S. (2008). Scientific consensus on water quality in the Great Barrier Reef. Reef Water Quality Protection Plan Secretariat; Brisbane.

Buckley, R. (2002). Public and Private Partnerships between Tourism and Protected Areas: the Australian situation. Journal of Tourism Studies, 13(1), 26-38. 
Buckley, R.C. \& Sommer, M. (2001). Tourism and Protected Areas: Partnerships in Principle and Practice. CRC Tourism, Gold Coast.

Bushell, R. \& Eagles, P. (eds) (2007). Tourism and Protected Areas: Benefits beyond Boundaries. The Vth IUCN World Parks Congress. Wallingford: CAB International.

Chadwick, V. (2004). Managing Tourism in the Great Barrier Reef Marine Park Doing it Better. In R. Buckley (Ed.) Tourism in Parks: Australian Initiatives. ICER, Griffith University, Gold Coast.

Coghlan, A. \& Prideaux, B. (2009). Responding to Stakeholder Research Needs using a Visitor Monitoring Survey: the case of the Great Barrier Reef Tourism Industry. Tourism in Marine Environments, 5(2/3): 187-199.

Department of Environment and Heritage (2004). Steps to Sustainable Tourism. http://www.environment.gov.au/heritage/publications/strategy/pubs/steps.pdf (accessed June 2011)

Dixon, J. A., Fallon Scura L. \& Van't Hof, T. (1993) Meeting Ecological and Economic Goals: Marine Parks in the Caribbean. Ambio, 22(2-3), 117-126

Driver, B.L. \& Brown, P.J. (1978). The opportunity spectrum concept and behaviour information in outdoor recreation resource supply inventories: a rationale. In: Lund, H.G., LABau, V.J., Folliot, P.F. and Robinson, D.W. (eds). Integrated Inventories of renewable natural resources: proceedings of the workshop. Ft. Collins, CO, USDA Forestry Service, Rocky Mt. Forest and Rangers Exp. Station Gen. Tech. Report RM-55: 24-31.

Eagles, P.F. J. (2002a) Trends in Park Tourism: Economics, Finance and Management Journal of Sustainable Tourism, 10 (2) 132-153

Eagles, P.F. J., McCool, S. \& Haynes, C. (2002b). Sustainable Tourism in Protected Areas: Guidelines for Planning and Management. IUCN Gland, Switzerland and Cambridge, UK.

Ecotourism Australia (2002). Cairns Charter for Partnerships in Ecotourism. http://www.ecotourism.org.au/cairnscharter.pdf (accessed June 2011)

Fabricius, K., De'ath,G., McCook, L., Turak, E \& McB. Williams, D. (2005). Changes in algal, coral and fish assemblages along water quality gradients on the inshore Great Barrier Reef. Marine Pollution Bulletin, 51 (1-4), 384-398.

Farm Chemical Cause Reef Pollution: WWF. (2009, January 23). Sydney Morning Herald online http://news.smh.com.au/breaking-news-national/farmchemicals-cause-reef-pollution-wwf-20090123-7o89.html (accessed June 2011).

Farrell, B. \& Twinning-Ward, L. (2004). Reconceptualising Tourism. Annals of Tourism Research, 31(2), 274-295. 
Farrell, B. \& Twinning-Ward, L. (2005). Seven Steps towards Sustainability: Tourism in the Context of New Knowledge. Journal of Sustainable Tourism, 13(2), 109-122.

Farsari, I., Butler, R.W. \& Szivas, E. (2010). The Use of Cognitive Mapping in Analysing Sustainable Tourism Policy: Methodological Implications. Tourism Recreation Research, 35(2), 145-160.

Fennell, D. A. \& B. Smale (1992) Ecotourism and Natural Resource Protection. Tourism Recreation Research, 17(1), 21-32.

Figgis, P. (1993) Ecotourism: Special interest or major direction? Habitat Australia, $8-11$

Fletcher, D. \& Fletcher, H. (2003). Manageable Predictors of Park Visitor Satisfaction: Maintenance \& Personnel. Journal of Park \& Recreation Administration, 21 (1), 21-37.

GBRMPA (2007)

http://www.gbrmpa.gov.au/corp_site/info_services/media/media_archive/2007

GBRMPA (2009a) http://www.gbrmpa.gov.au/onboard/home/rewards_program , accessed Jan 2009.

GBRMPA (2009b) http://www.reefhq.com.au/home/about_us

GBRMPA (date unknown a)

http://www.gbrmpa.gov.au/corp_site/info_services/science_management/mari ne_monitoring_program (accessed 10 June 2011)

GBRMPA (date unknown a) http://www.gbrmpa.gov.au/corp_site/info_services/science_management/mari ne_monitoring_program (accessed 10 June 2011)

GBRMPA (date unknown b) http://www.gbrmpa.gov.au/corp_site/key_issues/climate_change/management _responses/coral_bleaching_response_plan (accessed 10 June 2011)

GBRMPA (date unknown c) http://www.gbrmpa.gov.au/corp_site/key_issues/conservation/natural_values (accessed June 2011)

GBRMPA (date unknown d). Onboard: Tourism Operator's Handbook for the Great Barrier Reef. Available from http://www.gbrmpa.gov.au/onboard/home (accessed 10 June 2011).

Griffin, T. \& Vacaflores, M. (2004). A natural partnership : making national parks a tourism priority. CRC Sustainable Tourism, Gold Coast. 
Hall, C.M. (2010). Changing Paradigms and Global Change: From Sustainable to Steady State Tourism. Tourism Recreation Research, 35(2), 131-143.

Harriot, V.J. (2002). Marine Tourism Impacts and their Management on the Great Barrier Reef. CRC Reef Technical Report No. 46. CRC Reef Research Centre, Townsville.

Henderson, D.A., Chase, B.W. \& Woodson, B. (2002). Performance Measures for NPOs: How one organization developed a way to collect meaningful information. Journal of Accountancy, January 2002.

Herriman, J. (2008). Sustainability indicators. Talk given at the CAFNEC Sustainability Indicators Public Forum, Cairns, JCU 28 August.

Hoegh-Guldberg, H. (2008). Australian tourism and climate change. Carindale, Australia: Economic Strategies Pty Ltd.

Huybers, T. \& Bennett, J. (2002). Environmental Management and the Competitiveness of Nature-Based Tourism Destinations. Edward Elgar Publishing Limited, Cheltenham, UK.

Jamal, T. \& Stronza, A. (2009). Collaboration theory and tourism practice in protected areas: stakeholders, structuring and sustainability. Journal of Sustainable Tourism, 17(2), 169-189.

Kenchington, R.A. \& Day, J.C. (2011). Zoning, a fundamental cornerstone of effective Marine Spatial Planning: lessons learnt from the Great Barrier Reef, Australia. Journal of Coastal Conservation 15(2), 271-278.

Krippendorf, J. (1982). Towards new tourism policies: the importance of environmental and socio-cultural factors Tourism Management 3 (3) 135-148

Kruck, R. (2009, September). Developing Tourism Destinations through National Landscapes, Canberra, Australia.

Laing, J., Wegner, A., Moore, S., Weiler, B., Pfueller, S., Lee, D., Macbeth, J., Croy, G., \& Lockwood, M. (2008). Understanding Partnerships for protected area tourism: learning from the literature. CRC for Sustainable Tourism, Gold Coast.

Lane, B. (1994) Sustainable Rural Tourism Strategies: A Tool for Development and Conservation Journal of Sustainable Tourism, 2 (1\&2) 102-111

McCool, S. (2006). Managing for Visitor Experiences in Protected Areas: promising opportunities and fundamental challenges. Parks, 16(2), 3-10.

McCool, S.F. (2009) Constructing Partnerships for Protected Area Tourism Planning in an Era of Change and Messiness. Journal of Sustainable Tourism, 17(2), 133-148. 
McKercher, B. (1999). A Chaos Approach to Tourism. Tourism Management, 20, 425-434.

McKercher, B. \& Robbins. B. (1998). Business development issues affecting naturebased tourism operators in Australia. Journal of Sustainable Tourism, 6(2), 173-188.

Moore, S. \& Weiler, B. (2009). Tourism-protected area partnerships: stoking the fires of innovation. Journal of Sustainable Tourism, 17(2), 129-132.

Moscardo, G., Saltzer, R., Norris, A. and McCoy, A. (2004). Changing Patterns of Regional Tourism: Implications for tourism on the Great Barrier Reef. Journal of Tourism Studies 15(1), 34-50.

Queensland Tourism Industry Council (2008). Tourism Industry Skills Plan (current assessment) $2007-2010$.

http://www.qtic.com.au/files/Skils\%20Plan\%20V2.pdf (accessed April 2009).

Otto, J.E. \& Ritchie, J.R.B. 1996. The Service Experience in Tourism. Tourism Management, 17(3), 165-174.

Plummer, R. \& Fennell, D. (2009). Managing Protected Areas for Sustainable Tourism: prospects for adaptive co-management. Journal of Sustainable Tourism, 17(2), 149-168.

Rittel, H.W.J. \& Webber, M.M. (1973). Dilemmas in a General Theory of Planning. Policy Science, 4, 155-169.

Rudd, M.A. (2001). The non-extractive value of the spiny lobster, Panulirus argus, in the Turks and Caicos Islands. Environmental Conservation, 28(3), 226-234.

Ryan, C., \& Cessford, G. (2003). Developing a Visitor Satisfaction Monitoring Methodology: Quality Gaps, Crowding and Some Results. Current Issues in Tourism, 6 (6), 457-507.

Schluter, L., Peut, S. \& Mulqueeny, L. (2007). Keeping the Great Barrier Reef Great - The development of an innovative sustainable tourism partnership. In Proceedings of the $5^{\text {th }}$ International Coastal and Marine Tourism Congress (pp. 346-348). 11-15 September, AUT Auckland.

Shultis, J.D., \& Way, P.A. (2006). Changing conceptions of protected areas and conservation: linking conservation, ecological integrity and tourism management. Journal of Sustainable Tourism, 14(3), 223-237

Steffen, C. (2004). Parks and Tourism Partnerships: An Industry Perspective. In R. Buckley (Ed.) Tourism in Parks: Australian Initiatives. ICER, Griffith University, Gold Coast. 
Tonge, J. \& Moore, S.A. (2007). Importance-satisfaction analysis for marine-park hinterlands: a Western Australian case study. Tourism Management, 28 (3), 768-776.

Uyarra, M.C., Cote, I.M., Gill, J.A. Tich, R.R.T., Viner, D., \& Watkinson, A.R. (2005). Island-specific preferences of tourists for environmental features: Implications of climate change for tourism-dependent states. Environmental Conservation, 32(1), 11-19.

Williams, C.R. \& Polunin, N.V.C. (2000). Differences between protected and unprotected reefs of the Western Caribbean in attributes preferred by dive tourists. Environmental Conservation, 27(4), 382-391.

Wood, D. (1991). Corporate social performance revisited. Academy of Management Review, 16(4), 691-718. 
${ }^{\mathrm{i}}$ The research described here falls under the MTSRF research program to identify sustainable use and management of marine resources of the Great Barrier Reef and specifically the analysis of tourism use and impact on the Great Barrier Reef for managing sustainable tourism. Visitor surveys are administered monthly over a four year period to determine annual visitor usage patterns of the GBR and identify key trends and drivers of visitor patterns.

Table 1. Table 1 Summary socio-demographic and travel characteristics of GBR visitor survey $(\mathrm{N}=4800)$.

Table 2. Analysis of correlations between satisfaction measures.

Table 3: Respondents' satisfaction score in relation to the features that they felt influenced their satisfaction score. The three features of the model are highlighted in grey.

Figure 1. Links between natural resource management and tourism operators (Source: Adapted from Herriman 2008).

Figure 2. Possible links between GBRMP management and tourism operators

Figure 3. Changes in satisfaction measures for respondents between November 2006 to December 2008. 